is briefly discussed by V. A. Magnitsky (Priroda, 6, $46 ; 1961$ ). Naturally, this study will be applied only to the upper part of the mantle. A deep boring through the Mohorovičić discontinuity is projected, together with associated seismological, magnitometric, gravimetric and thermal flow studies.

Iron and manganese in ocean deposits. One of the scientific results of the Soviet research vessel Vityaz is the mapping of the concentration of iron-manganese concretions in the deposits of the Pacific Ocean, a brief account of which is given by N. L. Zenkevich and N. S. Skornyakova (Priroda, 2, 47; 1961). The average amount of these concretions in the area of their concentration is 8,600 tons $/ \mathrm{km} .{ }^{2}$. Submarine photographs reveal a very high proportion of the oceanic bottom rich in concretions. These results agree with the findings of $\mathrm{H}$. W. Menard and C. J. Shipek (Nature, 182, 1156; 1958).

Applied geochemistry. Geochemical landscapes, geochemical maps, dispersion aureoles and other problems of applied geochemistry are discussed by A. I. Perel'man (Priroda, 9, 98; 1961) and by A. A. Saukov and A. I. Perel'man (Priroda, 10, 59; 1961). Transformation of a desert. An article by V. N. Kumin (Priroda, 9, 61; 1961) gives a succinct account of the important irrigation scheme encompassed in the construotion of the large Karakum Canal, which carries the waters of the River Amu-Daria over 100,000 hectares of fertile desert lands. Various irrigational and biological problems are discussed.

Paloeoclimatological maps. G. I. Bushinsky (Priroda, 8, 54; 1961) describes palæoclimatological maps constructed on the basis of detailed analysis of lithogenesis by N. M. Strakov, who subdivided lithogenesis into four main types: humid, arid, glacial and volcanological-sedimentary. These types are mapped out on the world map as definite zones for the successive geological periods.

Stromatoliths as indicators of Polar wanderings. A. G. Vologdin (Priroda, 11, 102; 1961) reports that, in collaboration with Chinese geologists, he was able to study in detail stromatoliths (banded algal limestones) of Sinian age (1,200-600 million years) in the region of Zisyan Mountain, 110 miles east-northwest of Peking. It was discovered that these platy formations exhibited on their upper surface convexities which were assumed to be due to the heliotropism of the algae. Previous measurement of the orientation of the convexities of stromatoliths in this region and in the Enisey range showed a displacement of the pole by $40^{\circ}$ during the whole of the Sinian period. This method is considered to be adjunct to the usual palæomagnetic methods in the study of polar migration.
S. T. TOMKEIFFF

\title{
EXPORT MARKETING
}

$\mathrm{T}$ HE reasons why export marketing has not aroused the same enthusiasm in Britain as in, for example, Germany, the United States, or the U.S.S.R. are discussed in a recent issue of Planning which has been prepared from material supplied by N. A. H. Stacey, economic adviser of the General Electric Co.*.

The relative decline in British exports has often been attributed to the post-war resurgence of Western Germany and Japan, but the report suggests that the length of time which has now elapsed since the end of the Second World War considerably reduces the strength of this contention. Apart from this, two explanations are generally advanced. The first is that Britain has failed to adapt the commodity structure of its exports to changing world needs, and the second that it has failed to adapt its traditional export market pattern to new developments in world trade, in particular to the rapid increase in trade between highly industrialized nations since the War.

Where do the deeper faults lie, and how can they be remedied? The broadsheet coneentrates on what is believed to be one of the major reasons for Britain's lack of success in the world's export markets, namely, the British manufacturer's use of obsolete marketing techniques resulting from a neglect of market research.

The neglect of the marketing function by British industry must be attributed, paradoxically, to the long, unbroken success of British manufacturing industry. Since Britain was the supplier for more than a contury and a half of immense quantities of manufactured goods to the nations of the world, the notion that the process of manufacturing was the foundation of sound business gained an unwarranted sanctity. The corollary to this was the belief that

* Planning, Vol. 28, No. 459 (February 19, 1962): Problems of Txport Marketing. Pn. 19-38. (London: Political and Economic
Thanning, 1062.) 3 s. distribution, even if not unproductive, was not as valuable as manufacturing.

Such an attitude was justified while Britain was the sole mature industrial nation, as it was until the 1880 's. Now it has to share this position with a dozen or more industrial nations. The increased uniformity in the technical performance and efficiency of the goods made by reputable manufacturers in many of the industrial countries has meant that the effort needed for making a sale has assumed much greater importance.

The most important part of successful export effort in the competitive conditions of to-day is sound knowledge of the overseas markets. Familiarity with buyers' requircments, with the needs of the country, the preference of its population, and know. ledge of its recent economic and social development are the determinants of import requirements both to-day and to-morrow. It is part of intelligent marketing to discern requirements and to anticipate needs. Sound marketing is based on the assiduous collection of information to answer two questions. These are: (1) In what (new) markets can the manufacturer sell his existing range of products (with or without modification) or extend his sales? (2) What new products should be made for which there is a demand in his existing markets ?

The neglect of markoting, based on systematic marketing research overseas, is a dominant cause of Britain's present-day export predicament. To find out customers' preferences, to define the characteristics of the market, to estimate the volume of sale, to obtain information on products and prices of the competing manufacturers, to check on the efficiency of publicity, to secure economic information on likely developments in the future, theso uses of marketing research have not been properly considered by many British manufacturers. 
Why is this so? The explanation is to be found in Britain's past successes. Until recently, certain traditional markets were considered a prerogative of British industry, which led to institutional thinking instead of entrepreneurial action in overseas trading. For German, French or American firms evaluation of overseas markets in the post-war period was a necessity if they were to compete successfully with the already well-entrenched British manufacturers. Foreign manufacturers had to gain markets rather than find them--with the result that their marketing methods had an aggressiveness about them lacking in those of British markets.

The rest of this admirable broadsheet gives practical advice on how companies can develop vigorous marketing policies.

\section{OPERATIONAL RESEARCH AND THE HEALTH SERVICES}

FOR some time the Nuffield Provincial Hospitals Trust has been alive to the potentialities of the application of scientific method and modern management techniques to the planning and administration of the National Health Service. In recent years it has particularly encouraged the development of operational research studies in the socio-medical field. The full scope of the work being carried out is not well known, and during December 14-15, 1960, the Trustees arranged a symposium of interested persons for a general review of progress in the field*.

The conference was attended by most of the leading authorities on operational research in the fields of hospital and public health as well as representatives of the Ministry of Health, the Department of Health for Scotland and the Ministry of Health, Northern Ireland. At the same time, most bodies at present in a position to sponsor such research were represented.

The papers presented to the symposium were commissioned with the object of setting out the opportunities and the realities. The plan consisted of portraying the main issues as seen by a medical administrator, and of contrasting these with known operational research applications in the field and, as an astringent epilogue, of presenting accounts of two recent studies actually carried out.

Among the points brought out by the chairman, Prof. M. G. Kendall, in his concluding remarks were that there are widespread opportunities for the useful

* Nuffield Provincial Hospitals Trust. Towards a Measure of Medica Care-Operational Research in the Health Services-a Symposium Contributors: J. O. F. Davies, J. Brotherston, N. Bailey, G. Forsyth and R. Logan. Pp. xi +91 . (London: Oxford University Press. Published for the Nuffeld Provincial Hospitals Trust, 1962.) $5 s$. net. application of operational research techniques in studies of the National Health Service; such an application can be made at various levels of administration, and the number of operational research studies should be increased as soon as possible. Such studies could profitably examine not only the possibility of the National Health Service as it now exists but also the possibility of modification. The field to be covered is so vast that it would be difficult to specify an order of priority of importance in topies to be studied, but it should prove possible to draw up a classification. Recognizing that research on these matters may proceed in a number of locations, under a number of different administrations, there should be some arrangement to encourage inter-communication between the research units concerned. In particular, there should be periodic conferences of interested persons, and some form of centralized information service, to ensure that the nature and existence of present-day research is brought to the notice of all those who are likely to engage in it and use it.

The desirability of encouraging interest among hospital and local authorities in the possibilities of operational research in the National Health Service field should be recognized, and can be brought about by conferences, lectures or case-studies and direct encouragement from Central Government authorities. Recognizing the shortage of expert operational research personnel, Prof. Kendall suggested that there should be encouragement in universities and elsewhere for the formation of operational research units, the members of which could be made available for consultation or could provide leadership to authorities engaging in operational research studies.

\section{CALCUTTA SCHOOL OF TROPICAL MEDICINE}

IN the annual report of the Calcutta School of 1 Tropical Medicine and the Carmichael Hospital for Tropical Diseases, 1959-60*, the director, Dr. R. N. Chaudhuri, describes some of the more important observations made during that period.

A new technique, devised for experimental studies on amœbiasis, was successfully utilized in guinea pigs to produce a condition simulating chronic and recurring amcebiasis in man; this permitted direct studies on the evolution of the disease-process, and in vivo evaluation of amcbicidal drugs, without killing the animals. Human experiments have shown that asthmatic symptoms with high eosinophilia may result from ingestion of embryonated eggs of dog ascarids. This supports previous observations based on animal experiments and suggests a probable parasitic role in the ætiology of tropical eosinophilia.

* Annual Report of the Calcutta School of Tropical Medicine, and the Carmichael Hospital for Tropical Diseases, 1959-60. Pp. 131. (Calcutta: Calcutta School of Tropical Medicine and the Carmichael
Hospital for Tropical Diseases, 1961.)
Four types of protein malnutrition were categorized and follow-up studies showed the probability of one passing into another, indicating that the clinical pattern in them all resulted from the same ætiological process, namely, protein cum caloric deficiency, aggravated or precipitated by infection. Plant proteins, though not quite so good as milk, have been found useful in deficiency-states, and a pulse-cereal-green vegetable gruel sweetened with jaggery has produced encouraging results. It has the advantage of simple preparation at low cost and may considerably replace milk. The supply of vegetable proteins by a "supplementary feeding" programme to infants and young children in the low socio-economic group of the population may hold the promise of a prophylactic against this condition. Protein-rich biscuits were also prepared from protein hydrolysate of pulses and fishprotein hydrolysate. Clinico-pathological and experimental observations were also made on the nature and extent of hepatic involvement in diabetes mellitus. 